\title{
Intraocular Lymphoma
}

National Cancer Institute

\section{Source}

National Cancer Institute. Intraocular Lymphoma. NCI Thesaurus. Code C9184.

A lymphoma that arises within the eye. Signs and symptoms include decreased vision, uveitis, and vitreous floaters. 